\title{
The Antibacterial Activity of Amber Honey and White Honey on Pseudomonas aeruginosa Multi Resistant (PaMR) and Methicillin Resistant Staphylococcus aureus (MRSA)
}

\author{
Faisal Yusuf Ashari ${ }^{1}$, Setio Harsono ${ }^{2^{*}}$, Manik Retno Wahyunitisari ${ }^{2}$
}

${ }^{1}$ Faculty of Medicine, Universitas Airlangga, Surabaya, Indonesia.

${ }^{2}$ Department of Microbiology, Faculty of Medicine, Universitas Airlangga, Surabaya, Indonesia.

\section{A B S T R A C T}

Introduction: Infection of burn wound is a chronical disturbance to the skin, which is caused by Staphylococcus aureus and Pseudomonas aeruginosa, but lately many cases found that both bacteria have been resistant to the antibiotic. To overcome the infection caused by those bacteria, it is important to search for natural substance that has antibacterial activity to both bacteria. The power of natural substance is underestimated. Studies reveal that honey can be more effective for healing burns than modern medicine. The previous research revealed that amber honey and white honey were used as an alternative treatment against Pseudomonas aeruginosa Multi Resistant (PaMR) and Methicillin Resistant Staphylococcus aureus (MRSA). The aim of this study was to evaluate the antibacterial activity of amber honey and white honey on PaMR and MRSA.

Methods: This research was conducted by performing antibacterial test phase, determining Minimum Inhibitory Concentration (MIC), and determining comparison value of antibacterial activity from amber honey and white honey to tetracycline.

Results: The result of this research showed that both amber honey and white honey have antibacterial activity to both bacteria, by way of stronger antibacterial activity from white honey than amber honey. Amber honey and white honey have the same PaMR activity. MIC of white honey was $7.1 \%$ (to MRSA) and $12.3 \%$ (to PaMR), while MIC of amber honey was $10 \%$ (to MRSA) and $12.5 \%$ (to PaMR). The comparison value of antibacterial activity between amber honey and white honey to tetracycline for MRSA was equal to 1:1.08 $\times 10-4$ and 1:1.62 $\times 10-4$. The comparison value of antibacterial activity between amber honey and white honey to tetracycline for PaMR was equal to $1: 5.62 \times 10-6$ and $1: 1.03 \times 10-5$.

Conclusion: Amber honey and white honey have antibacterial activity against MRSA and PaMR.

๑) 2020 JUXTA: Jurnal IImiah Mahasiswa Kedokteran Universitas Airlangga. Available at https://e-journal.unair.ac.id/juxta

*Correspondence: setioharsono@fk.unair.ac.id

JUXTA: Jurnal IImiah Mahasiswa Kedokteran Universitas Airlangga

p-ISSN: 1907-3623; e-ISSN: 2684-9453

DOI: $10.20473 /$ juxta.V11I22020.74-78

Open access under Creative Commons Attribution-ShareAlike 4.0 International License (CC-BY-SA)

\section{ARTICLE INFO}

Article history:

Received 13 July 2020

Accepted 2 August 2020

\author{
Keywords: \\ Infection of Burn Wound, \\ Amber Honey, \\ White Honey, \\ MRSA, \\ PaMR.
}




\section{Introduction}

One of many health problems in the community that can never be completely resolved is infection. Infectious diseases caused by bacteria are reported to still be an important health problem in developing countries, including Indonesia. ${ }^{1}$ One type of infection is an infection of burn wound that results in inflammation. Burns are damage to the skin caused by direct contact with heat (fire, hot objects), chemicals, and electricity. ${ }^{2}$ If not treated quickly, it will cause infection due to dead tissue which will become a fertile place for bacterial growth. The result of this infection is in the form of pus. ${ }^{3}$ Inflammation of festering burns at weekly intervals from one of the cases at Brazilian da Asa Norte Hospital reported that there had been the presence of Staphylococcus aureus as much as $28.4 \%$ and Pseudomonas aeruginosa as much as $26.9 \% .{ }^{4}$

$P$. aeruginosa is a Gram negative, aerobic, and moving bacterium using flagellum, and is an opportunistic bacterium. $P$. aeruginosa infection causes disease in various tissues, including the respiratory tract, eyes, urinary tract, and skin., 6 Treatment for $P$. aeruginosa infections uses antibiotics penicillin group, cephalosporin group, aminoglycoside group, and fluoroquinolone group. Reported by the European epic study, $P$. aeruginosa is resistant to several antibiotics: gentamicin (46\%), imipenem (21\%), ceftazidime (27\%), ciprofloxacin $(26 \%)$, and ureidopenisilin (37\%). ${ }^{7}$

S. aureus is a Gram-positive, rounded bacterium, arranged in an irregular sequence like grapes, easily grows in a variety of seedlings and has an active metabolism, and produces pigments that vary from white to dark yellow. $S$. aureus can cause inflammation, abscesses, etc. About $40 \%$ of $S$. aureus that can be isolated in hospitals are known to be resistant to various types of antibiotics, but are still sensitive to vancomycin, clindamycin, trimethoprimsulfamethoxazole, and gentamicin. ${ }^{8}$ One type of $S$. aureus that is resistant is Staphylococcus aureus Methicillin Resistant (MRSA). MRSA is widely distributed as a pathogen in the form of a group of bacteria, and other than being resistant to methicillin, MRSA is also resistant to penicillin, oxasilin, and erythromycin. ${ }^{9}$ With the discovery of several cases of resistance, the cost of treatment and status of the patient's disease condition will be higher. Therefore, one alternative treatment for burn infection other than antibiotics is derived from natural ingredients.

Honey is reported to have antibacterial activity against $P$. aeruginosa, Escherichia coli, S. aureus, and Streptococcus pyogenus. ${ }^{10}$ Honey is a natural liquid from flower essence (floral nectar) or other parts of plants (extra floral nectar) collected by honey bees. ${ }^{11}$ White honey and amber honey are examples of types of honey based on their color. White honey has a higher consistency compared to amber honey. ${ }^{12}$ Antibacterial activity in honey is caused by high levels of honey sugar, hydrogen peroxide $\left(\mathrm{H}_{2} \mathrm{O}_{2}\right)$, high acidity of honey, and organic compounds (polyphenols, flavonoids, and glycosides) which are antibacterial. High sugar levels will inhibit the growth of bacteria, thus it cannot live and reproduce. The presence of $\mathrm{H}_{2} \mathrm{O}_{2}$ radical compounds that are produced enzymatically makes honey has a very acidic $\mathrm{pH}$, thus it can kill pathogenic microorganisms.

Based on scientific information about the antibacterial activity of amber honey and white honey against bacteria in festering burns, it is necessary to test the antibacterial activity of amber honey and white honey against MRSA and PaMR antibacterial tests.

\section{Methods}

In this study, we used amber honey and white honey from the island of Sumbawa, Indonesia, which was purchased by CV. Syan Bimpar Utama, Jakarta. The test was conducted at Microbiology Laboratory of Faculty of Medicine, Universitas Airlangga on September-October 2013.

The study was conducted pre-experimentally using 12 dose for each test of bacteria. MRSA and PaMR are inoculated into Nutrient Broth as a complete aseptic, and then incubated in an incubator at $370^{\circ} \mathrm{C}$ for $18-24$ hours.

For antibacterial activity test, a total of $20 \mu \mathrm{L}$ of each bacterial suspension was put into a sterile petri dish, then the nutrient that was still runny $\left(40-450^{\circ} \mathrm{C}\right)$ was poured into it. After being homogenised and allowed to freeze, several holes are made in the nutrient agar using a perforator. $\mathrm{A}$ total of $50 \mu \mathrm{L}$ of test material (honey) was put into the holes. All petri dishes were incubated in an incubator at $370^{\circ} \mathrm{C}$ for 18-24 hours. The diameter of the inhibition formed around the hole was observed. The formation of inhibitory diameter around the hole indicated the antibacterial activity of the test material.

In determining Minimum Inhibitory Concentration (MIC), a certain amount of honey was put into a petri dish, then a gradual dilution was performed by adding a certain amount of nutrients in order to reach a certain concentration variation. After being homogenised and allowed to freeze, a dose of test bacteria was etched on the surface of the nutrient agar. All petri dishes were incubated upside down in an incubator at $370^{\circ} \mathrm{C}$ for $18-24$ hours. MIC was in the petri dish with the smallest concentration of test material without colony growth.

For the comparative test of antibacterial activity of amber honey and white honey against tetracycline, a total of $40 \mu \mathrm{L}$ of bacterial suspension was put into a sterile petri dish, then the liquid nutrient agar $\left(40-450^{\circ} \mathrm{C}\right)$ was poured into it. After being homogenised and allowed to freeze, several holes were made in the nutrient agar with a perforator. A total of $50 \mu \mathrm{L}$ of test material (honey) and comparative antibiotic (tetracycline) in various concentrations were put into each hole. All petri dishes were incubated in an incubator at $370^{\circ} \mathrm{C}$ for $18-24$ hours. The diameter of the inhibition formed around the hole was measured by the callipers.

\section{Results}


Parameters analyzed in the honey include acidity, refractive index, water content, viscosity, and specific gravity. Analysis was done to see the quality of the honey used, with reference to SNI-01-3545-2004 concerning honey. The results of honey quality analysis are shown in Table 1.

Table 1. Results of quality analysis of amber honey and white honey.

\begin{tabular}{|c|c|c|c||}
\hline Criteria & \multirow{2}{*}{ SNI } & \multicolumn{2}{|c|}{ Type of Honey } \\
\cline { 3 - 4 } & $\begin{array}{c}\text { White } \\
\text { Honey }\end{array}$ & $\begin{array}{c}\text { Amber } \\
\text { Honey }\end{array}$ \\
\hline $\begin{array}{c}\text { Similarity } \\
(\mathrm{ml} \mathrm{NaOH} \mathrm{1} \\
\mathrm{N} / \mathrm{kg})\end{array}$ & 50 & 40.337 & 38.071 \\
\hline Refractive index & $1.5044-1.4745$ & 1.4803 & 1.4781 \\
\hline $\begin{array}{c}\text { Water content } \\
(\%) \text { (max) }\end{array}$ & 22 & 22.6 & 23.4 \\
\hline $\begin{array}{c}\text { Viscosity (poise) } \\
\text { (min) }\end{array}$ & 10.7 & 18 & 16 \\
\hline $\begin{array}{c}\text { Specific gravity } \\
\text { (g/ml) }\end{array}$ & $1.354-1.4164$ & 1.4136 & 1.398 \\
\hline $\mathrm{pH}$ & $3.2-4.5$ & 4.08 & 4.17 \\
\hline
\end{tabular}

The results of amber honey and white honey activity testing on MRSA and PaMR can be seen in Table 2.

Table 2. Test results of antibacterial activity of amber honey and white honey against MRSA and PaMR.

\begin{tabular}{|c|c|c|c|}
\hline \multirow{2}{*}{$\frac{\text { Type of }}{\text { Honey }}$} & \multirow{2}{*}{$\frac{\text { Concentr }}{\underline{\text { ation }}}$} & \multicolumn{2}{|c|}{$\frac{\text { Inhibitory zone diameter }}{(\mathrm{mm})}$} \\
\hline & & MRSA & PaMR \\
\hline White Honey & $50 \%$ & $\underline{36.5}$ & 16.3 \\
\hline Amber Honey & $50 \%$ & 31.5 & $\underline{15.6}$ \\
\hline
\end{tabular}

The results of MIC determination of amber honey and white honey against MRSA and PaMR can be seen in Table 3.

Table 3. Results of MIC determination of amber honey and white honey against MRSA and PaMR.

\begin{tabular}{|c|rr|rc|}
\hline Concentration & \multicolumn{2}{|c|}{ Amber Honey } & \multicolumn{2}{c|}{ White Honey } \\
\hline$(\% \mathrm{v} / \mathrm{v})$ & MRSA & PaMR & MRSA & PaMR \\
0 & + & + & + & + \\
2 & + & + & + & + \\
4 & + & + & + & + \\
6 & + & + & + & + \\
6.5 & + & + & + & + \\
7 & + & + & - & + \\
7.25 & + & + & - & + \\
7.5 & + & + & - & + \\
7.75 & + & + & - & + \\
8 & + & + & - & + \\
10 & - & + & - & + \\
10.5 & - & + & - & + \\
11 & - & + & - & + \\
11.5 & - & + & - & + \\
12 & - & + & - & + \\
12.3 & - & + & - & - \\
12.5 & - & - & - & - \\
13 & - & - & - & - \\
\hline
\end{tabular}

Notes :

$+:$ there is a growth of bacterial colonies
$-:$ there is no growth of bacterial colonies

Comparative data on antibacterial activity of tetracycline, amber honey, and white honey against MRSA and PaMR can be seen in Table 4 and 5 .

Table 4. Comparison of tetracycline, amber honey, and white honey antibacterial activity against MRSA.

\begin{tabular}{|c|c|c|c|}
\hline $\begin{array}{c}\text { Type of } \\
\text { substance } \\
\text { antibacterial }\end{array}$ & $\begin{array}{c}\text { Concentration } \\
\text { C (ppm) }\end{array}$ & Log C & $\begin{array}{c}\text { Inhibitory } \\
\text { diameter } \\
\text { (mm) } \\
\text { towards } \\
\text { MRSA }\end{array}$ \\
\hline Tetracycline & 100 & 2 & 25.26 \\
& 200 & 2.302029996 & 28.5 \\
& 300 & 2.477121255 & 30.3 \\
& 400 & 2.602059991 & 31.03 \\
Amber Honey & 100000 & 2.698970004 & 31.5 \\
& 200000 & 5 & 16.7 \\
& 300000 & 5.301029996 & 17.5 \\
& 400000 & 5.477121255 & 18.3 \\
& 500000 & 5.698970004 & 20.1 \\
White Honey & 100000 & 5 & 18.3 \\
& 200000 & 5.301029996 & 21.21 \\
& 300000 & 5.477121255 & 23.2 \\
& 400000 & 5.602059991 & 26.4 \\
& 500000 & 5.698970004 & 32.1 \\
\hline
\end{tabular}

Based on Table 4, to get an appeal value, the standard curve between log tetracycline concentration and MRSA was obtained by the straight line equation for the antibacterial activity of tetracycline against MRSA such as $y=9.1219 x+7.2792$ with a correlation coefficient of 0.9822 . From Table 4, the standard curve was obtained as shown in Figure 1. 


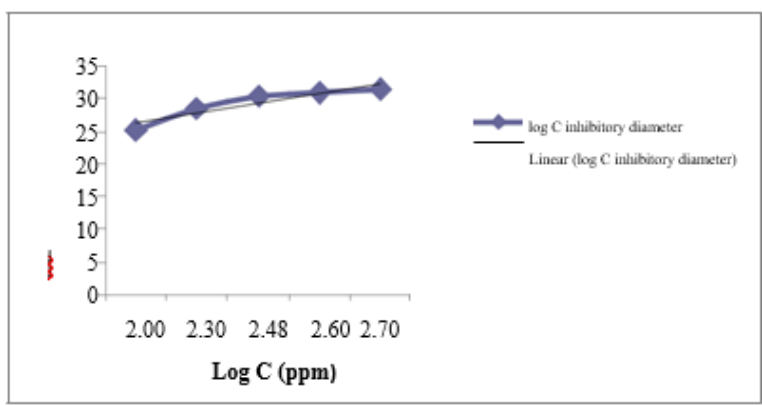

Figure 1. The standard curve for tetracycline with respect to MRSA with the equation.

The results of comparative tests on the antibacterial activity of white honey and amber honey with respect to MRSA is shown in Figure 2.

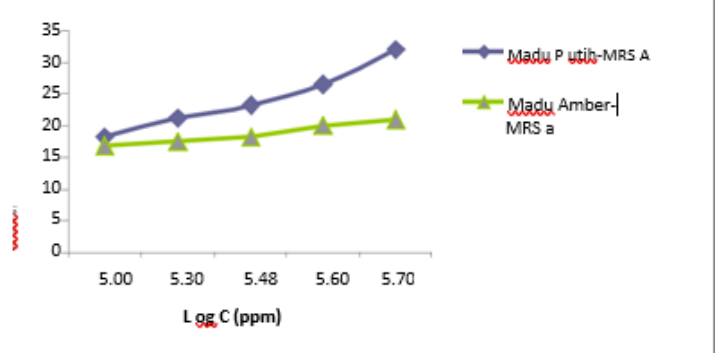

Figure 2. The curve of antibacterial test of white honey and amber honey activity against MRSA.

For comparative data on the antibacterial activity of tetracycline, amber honey, and white honey against PaMR can be seen in Table 5 .

\begin{tabular}{|c|c|l|c|}
\hline $\begin{array}{l}\text { Type of } \\
\text { substance } \\
\text { antibacterial }\end{array}$ & $\begin{array}{c}\text { Concentration } \\
\text { C (ppm) }\end{array}$ & Log C & $\begin{array}{l}\text { Inhibitory } \\
\text { diameter } \\
\text { (mm) } \\
\text { towards } \\
\text { PaMR }\end{array}$ \\
\hline Tetracycline & 1000 & 3 & 18.02 \\
& 2000 & 3.301029996 & 20.31 \\
& 4000 & 3.602059991 & 23.22 \\
Amber & 8000 & 3.903089987 & 25.47 \\
Honey & 16000 & 4.204119983 & 30.68 \\
& 7000000 & 5.77815125 & 16 \\
& 800000 & 5.84509804 & 16.5 \\
& 900000 & 5.903089987 & 17.1 \\
& 1000000 & 6 & 17.5 \\
& 600000 & 5.77815125 & 16.8 \\
White & 700000 & 5.84509804 & 17.75 \\
Honey & 800000 & 5.903089987 & 18.9 \\
& 900000 & 5.954242509 & 20.81 \\
& 1000000 & 6 & 21.5 \\
\hline
\end{tabular}

Based on Table 5, to get an appeal value, the standard curve between log tetracycline concentration and PaMR was obtained by the straight line equation for the antibacterial activity of tetracycline against the PaMR with $y=3.048 x+14.396$ with a correlation coefficient of 0.9707 . The data on Table 5 was processed through linear regression analysis, producing a standard curve graph seen in Figure 3.

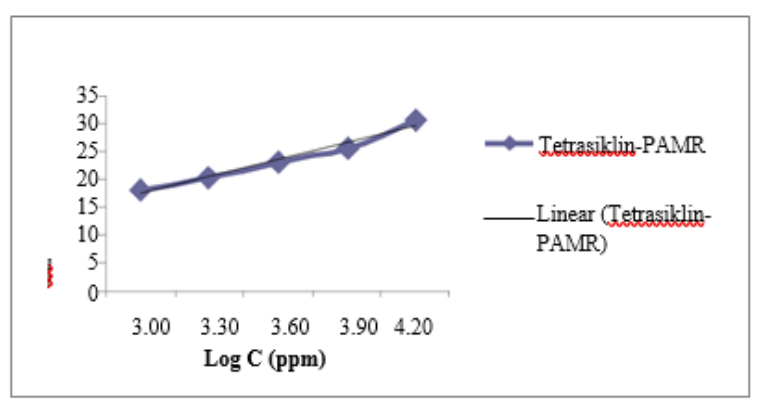

Figure 3. The standard curve of tetracycline against PaMR with the equation $y=3.048 x+14.396$, with $R 2=0.9707$.

The results of comparative tests on the antibacterial activity of white honey and amber honey against PaMR is shown in Figure 4.

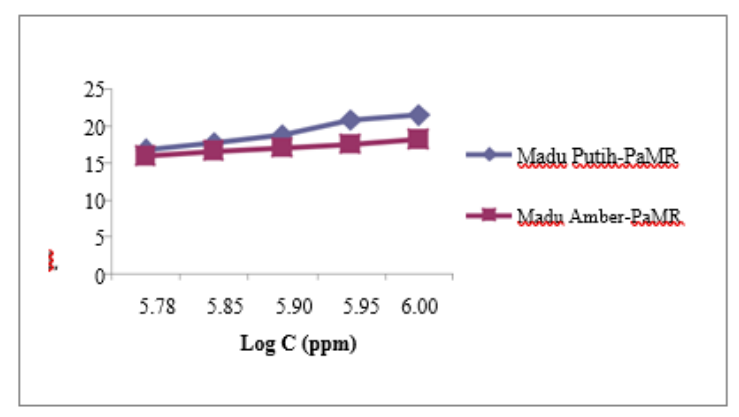

Figure 4. The curve of antibacterial test of white honey and amber honey activity against PaMR.

\section{Discussion}

From Table 1, it can be seen that only the water content criteria could not be fulfilled by amber honey and white honey. The difference in yield water content in the second analysis of honey with SNI standard was quite small. Therefore, amber honey and white honey used in this study had good quality.

Based on Table 2, it shows both honey's produce zone of inhibition against each test bacteria. The inhibitory diameter of the second inhibition zone of honey against MRSA was not completely clear, but it was yellowish in color, which was due to the bacteriostatic activity of both honey against MRSA. In the second zone of inhibition of honey against PaMR, there were still some colonies with smaller numbers and sizes than those outside the zone of inhibition. This shows that both honey were also bacteriostatic towards PaMR. 
Based on Table 3, MIC of amber honey to MRSA was $10 \%$ and against PaMR was $12.5 \%$. MIC of white honey against MRSA was $7 \%$ and against PaMR was $12.3 \%$. This shows that activity of the antibacterial properties of white honey against MRSA and PaMR weere stronger than amber honey against these two bacteria. Based on the results of the study, it also shows that MRSA was more sensitive to both honey than PaMR.

From Figure 2, it is known that white honey has better antibacterial activity against MRSA test bacteria than amber honey, because the graph of antibacterial activity of white honey was above the amber honey graph.

To get the comparative test value, one concentration and inhibition diameter data were taken from amber honey and white honey against MRSA. Amber honey with a concentration of $100,000 \mathrm{ppm}$ produced an inhibitory diameter of $16.7 \mathrm{~mm}$, while white honey with a concentration of $100,000 \mathrm{ppm}$ produced an inhibitory diameter of $18.3 \mathrm{~mm}$. Values of 16.7 and 18.3 were substituted into the equation of $y=9.1219 x+7.2792$ as the value of $y$, so that the resulting $x$ value and the antilog were 10.78368756 and 16.1498819 respectively. By using the comparative test formula, the comparative value of the antibacterial activity of amber honey against tetracycline for MRSA was $1: 1.08 \times 10-4$, while white honey against tetracycline for MRSA was 1:1.62 x 10-4.

From Figure 4, it is known that white honey has better activity antibacterial against PaMR test bacteria compared to amber honey, because the antibacterial activity chart of white honey was above the amber honey graph, thus it is known that white honey has better antibacterial activity against both test bacteria than amber honey, because both graphs of antibacterial activity of white honey which were above amber honey chart. The same calculation was performed on antibacterial activity of amber honey against PaMR. Amber honey with a concentration of 600,000 ppm produced an inhibitory diameter of $16 \mathrm{~mm}$, while white honey with a concentration of $600,000 \mathrm{ppm}$ produced an inhibitory diameter of $16.8 \mathrm{~mm}$. Values of 16 and 16.8 were substituted into the equation of $y=3.048 x+14.396$ as the value of $y$, so that the resulting $x$ and antilog values were 3.374544994 and 6.175646302 respectively. By using the comparative test formula, the comparative value of the antibacterial activity of amber honey against tetracycline for PaMR was 1:5.62 x 10-6, while white honey against tetracycline for PaMR was 1:1.03 x 10-5.

\section{Conclusion}

From the research conducted it can be concluded that amber honey and white honey have antibacterial activity against MRSA and PaMR. MIC of amber honey and white honey against MRSA was $10 \%$ and $7 \%$. MIC of amber honey and white honey against PaMR was $12.5 \%$ and $12.3 \%$. The comparative value of the antibacterial activity of amber honey and white honey against tetracycline for MRSA was 1:1.08 $\times 10-4$ and 1:1.62 $\times 10-4$. Comparative value of antibacterial activity of amber honey and white honey against tetracycline for PaMR was 1:5.62 x 10-6 and $1: 1.03 \times 10-5$

In the future, this research can be continued by testing the antibacterial activity of honey against various other bacterial strains.

\section{CONFLICT OF INTEREST}

The author stated there is no conflict of interest in this study.

\section{REFERENCES}

1. Muhaimin $M$, Liang $O$, Ratnaningsih E, Purwantini $E$ and Retnoningrum D. Optimasi Proses Overproduksi, Pemurnian dan Karakterisasi Protein Mga Sebagai Molekul Target Untuk Pencegahan Infeksi oleh Streptococcus Pyogenes. 2009; 8.

2. Makanan DKDJPOd. Kompendia Obat Bebas. Direktorat Jenderal Pengawasan Obat dan Makanan, Depkes. R.I, 1997.

3. Nasroudin. Penyakit Infeksi di Indonesia: Solusi Kini \& Mendatang. Airlangga, 2007.

4. Macedo JLSd and Santos JB. Bacterial and Fungal Colonization of Burn Wounds. Memórias do Instituto Oswaldo Cruz. 2005; 100: 535-9.

5. Ketchum PA. Microbiology Concepts and Applications. New Jersey: John Wiley \& Sons, Inc., 1998.

6 . Todar KG. Todar's Online Textbook of Bacteriology. 2004.

7. Katzung BG. Basic and Clinical Pharmacology. 2 ed. New York: Lange Medical Publications, 2001.

8. Martínez-Aguilar G, Hammerman WA, Mason EO, Jr. and Kaplan SL. Clindamycin Treatment of Invasive Infections Caused by Community-Acquired, MethicillinResistant and Methicillin-Susceptible Staphylococcus aureus in Children. The Pediatric Infectious Disease Journal. 2003; 22: 593-8.

9. Karchmer AW. From Theory to Practice: Resistance in Staphylococcus aureus and New Treatments. Clinical Microbiology and Infection. 2006; 12: 15-21.

10. Menon T and Mullai V. Antibacterial Activity of Honey against Pseudomonas aeruginosa. Indian Journal of Pharmacology. 2005; 37: 403.

11. MIRAGLIO A. Honey-Health and Therapeutic Qualities [en ligne]. 2003. Disponible sur: http://www biologiq nI/UserFiles/Compendium\% 20Honey. 202002.

12. Zewdi A. Wukro White Honey: (2007, accessed 20 April 2008). 